\title{
Mainstreaming Technopreneurship in Selected Higher Education Degree Programs
}

\author{
FELSA AVAN-LABIS \\ ORCID No. 0000-0001-5635-5298 \\ drfavanlabis@gmail.com \\ Liceo de Cagayan University \\ Cagayan de Oro City, Philippines
}

\begin{abstract}
Technology-based entrepreneurship or technopreneurship is the healthy interplay of viable technology ideas, technology skill, and entrepreneurial mindset. It is a significant source of good jobs that create wealth. A shift to this type of entrepreneurship is now being considered by more and more educational institutions worldwide. This study provides a comprehensive picture of mainstreaming technopreneurship in Higher Education Institution (HEI) degree programs. The paper reviewed the educational system attributes to determine the feasibility of mainstreaming technopreneurship. Findings reveal that (a) HEIs educational system often differ dramatically, particularly in terms of accreditation and preferred mainstreaming schemes; and (b) substantial interest among non-business students suggests a welcome opportunity to introduce formally technopreneurship education beyond the stereotype business school.
\end{abstract}

Keywords: Technopreneurship, mainstreaming, content, context, inputs, outputs, outcome

\section{INTRODUCTION}

Technology entrepreneurship or technopreneurship is a novel form of entrepreneurship because it is essentially technology-based (Oukil, 2006). Innovation is important for it fuels economic growth. Globalization has made innovation even more important in order for economies to remain competitive.

Technopreneurship is not a product but a process of synthesis in engineering the future of a person, an organization, a nation, and the world. Strategic directions or decision-making processes are becoming more and more demanding and 
complex, requiring universities and in site professional development programs and training to produce potential strategic thinkers who have the skills to succeed in a rapidly changing global environment (entrepreneurship.org).

Traditional university programs, however, lack the teaching methods to turn today's students into creative, innovative, visionary global leaders who understand the importance of technopreneurship (entrepreneurship.org.). Currently, the teaching of technopreneurship is not yet sufficiently integrated into the higher education institutions' curricula. There is no doubt that innovative and viable business ideas can emerge from technical, scientific, and creative studies. The real challenge, however, is how to build inter-disciplinary schemes such as integrating technopreneurship education into the mainstream education that is accessible to all students, creating teams for the development and exploitation of business ideas, and mixing students from economic and business studies with students from other faculties with different backgrounds.

This study provides a comprehensive picture of mainstreaming technopreneurship into higher education institutions' degree programs. Further, the study explored the educational system attributes of the HEIs.

\section{FRAMEWORK}

The study is anchored on the premise that the educational system factors are determinants of the feasibility of mainstreaming technopreneurship in higher education degree programs. The educational factors are variables identified as Context, Input, Process, Output, and Outcome. It is assumed that the context (a type of institution and accreditation) input (faculty development and facilities), process (mainstreaming schemes) and output (technical and entrepreneurial aptitude) variables have a significant effect on the outcome variable. The outcome variable pertains to the willingness of students to enroll in the technopreneurship subject. Figure 1 illustrates the framework of the study. 


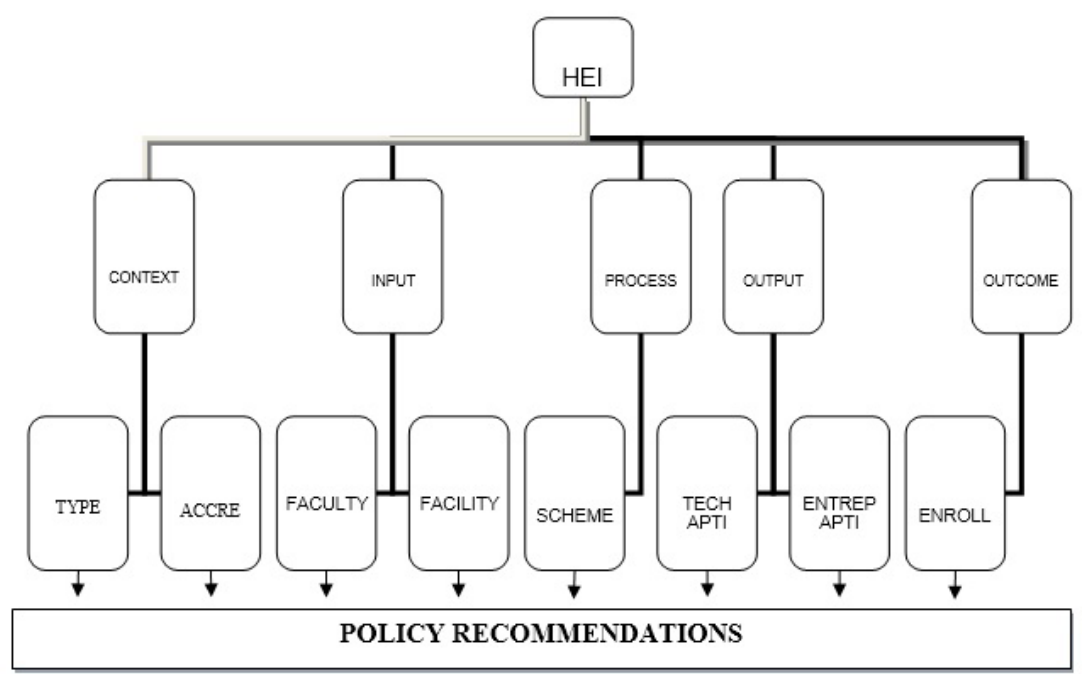

Figure 1. Logical Framework

\section{OBJECTIVES OF THE STUDY}

The study aimed at providing a comprehensive picture of the mainstreaming of technopreneurship into the higher education institutions' degree programs. Specifically, the study (1) examined, analyzed, and synthesized the educational system of Higher Education Institutions to determine the feasibility of mainstreaming the subject; (2) analyzed the context, inputs, processes, and outputs of the various mainstreaming schemes in the different HEIs to determine the viability of the scheme; and (3) analyzed the context, inputs, processes and outputs of mainstreaming technopreneurship to determine the level of demand for technopreneurship education among HEI students.

\section{Analytical Framework and Data Analysis}

Cluster analysis is a set of techniques used to identify groups of similar variables and objects based on their characteristics (Girish et al., 1983). Such analysis uses predetermined criteria to group individuals or organizations into clusters that are internally homogeneous and externally heterogeneous. The three 
sequential steps required for such analysis are partitioning, interpretation, and profiling (Bagozzi et al., 1998).

To meet the objectives of the study, the researcher developed a model to help structure, analyze, and present the results of the study in a clear and coherent way. The underlying assumption of the study is that mainstreaming technopreneurship has the potential to encourage technopreneurship, to foster the right mindset among students, and to develop relevant technical skills. In time, technopreneurship will contribute to economic growth, job creation, innovation, and wealth generation.

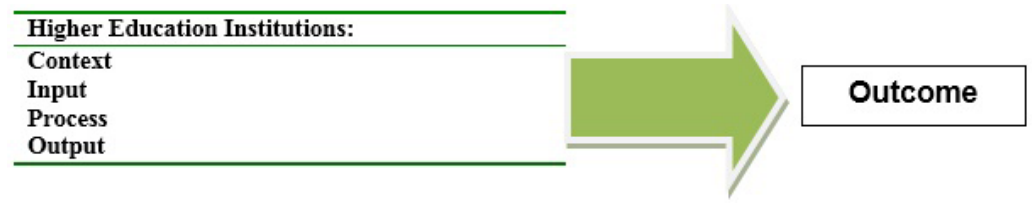

Figure 2. A Framework for Mainstreaming Technopreneurship

Figure 2 shows the interplay of the research variables, namely Context, Inputs, Process, Output, and Outcome.

As illustrated, mainstreaming technopreneurship is achieved by focusing on the different yet related system dimensions that require parallel actions. As argued by Gibb (2005), based on American, Asian, and European experiences, an HEI is entrepreneurial when among other things it engages actively with the wider stakeholder community; internally organizes to provide a stronger central steer to entrepreneurial endeavor; promotes the creation of science parks, incubators, technology-transfer offices; accepts wider responsibility for the personal development of students and staff; recruits entrepreneurial staff and appoints change agents; builds rewards systems beyond those relating to research, publication and teaching criteria; ensures that the concept of entrepreneurship is embedded in all faculties and disciplines and integrated into the curriculum; and encourages a wide range of interdisciplinary activity.

The framework of this study has it that the HEIs can be analyzed in a structured and comprehensive way by exploring the five system dimensions.

Context refers to the school's classification whether private or public and the school's quality of instruction measured in terms of accreditation status.

Input pertains to the school's institutional infrastructure such as faculty development program and facilities to support technopreneurship education. 
Process refers to everything that goes on in a program from startup to outcomes and outputs. In this study, the process variable includes strategies the HEIs will use to mainstream technopreneurship into their higher degree program.

Output refers to the students' level of competence brought about by the learning opportunities and environment offered by the HEIs. Product or output is something that is produced by a program, including an educational or manufacturing process. Thus, in this study, the output variable consists of the students' technical and entrepreneurial aptitudes.

The outcome variable goes beyond the output. It is the ultimate end the program desires to achieve. In this study, the outcome variable is the level of demand for technopreneurship education.

\section{Measurement of Variables for Cluster Analysis}

The following variables were used as the basis for k-means clustering:

Table 1. Variable for Cluster Analysis

\begin{tabular}{|c|c|c|}
\hline Context: & $\mathrm{Xl}$ : Classification & $\begin{array}{l}\text { Private (1) } \\
\text { Public (2) }\end{array}$ \\
\hline & X2: Accreditation Status & $\begin{array}{l}\text { Accredited (1) } \\
\text { Non-accredited (2) }\end{array}$ \\
\hline \multirow[t]{2}{*}{ Input: } & X3: Faculty Development & $\begin{array}{l}\text { Poor (1) } \\
\text { Fair (2) } \\
\text { Good (3) } \\
\text { Very Good (4) } \\
\text { Excellent (5) }\end{array}$ \\
\hline & X4: School Facilities & $\begin{array}{l}\text { Poor (1) } \\
\text { Fair (2) } \\
\text { Good (3) } \\
\text { Very Good (4) } \\
\text { Excellent (5) }\end{array}$ \\
\hline Process: & X5: Mainstreaming Scheme & $\begin{array}{l}3 \text { or } 6 \text { unit cognate course (1) } \\
\text { Topic in a subject (2) } \\
\text { Combo of } 1 \& 2(3) \\
\text { All schemes (4) } \\
\text { As a Tech Yoc Course (5) }\end{array}$ \\
\hline Output: & $\begin{array}{l}\text { X6: Technical Aptitude } \\
\text { X7: Entrepreneurial Aptitude }\end{array}$ & $\begin{array}{l}\text { Low (1) } \\
\text { Medium (2) } \\
\text { High (3) }\end{array}$ \\
\hline Outcome: & $\begin{array}{l}\text { X8: } \% \text { of students who will } \\
\text { Enroll the subject }\end{array}$ & $\begin{array}{l}\text { Low (1) } \\
\text { Medium (2) } \\
\text { High (3) }\end{array}$ \\
\hline
\end{tabular}




\section{METHODOLOGY}

The researcher conducted a general survey among Higher Education Institutions in Cagayan de Oro City, Gingoog City, and Misamis Oriental and an in-depth survey of students and teachers. The general survey had questions designed to determine the profile of the HEIs and the feasibility of the mainstreaming scheme among the HEIs. The in-depth survey explored the students' technical and entrepreneurial competencies and willingness to enroll the subject and the teachers' insights and teaching competencies.

\section{RESULTS AND DISCUSSION}

Clustering of Higher Education Institutions

The 22 Higher Education Institutions in Cagayan de Oro City and Misamis Oriental were clustered according to educational system attributes that can facilitate technopreneurship education. Results of the cluster analysis are shown below.

Similarity

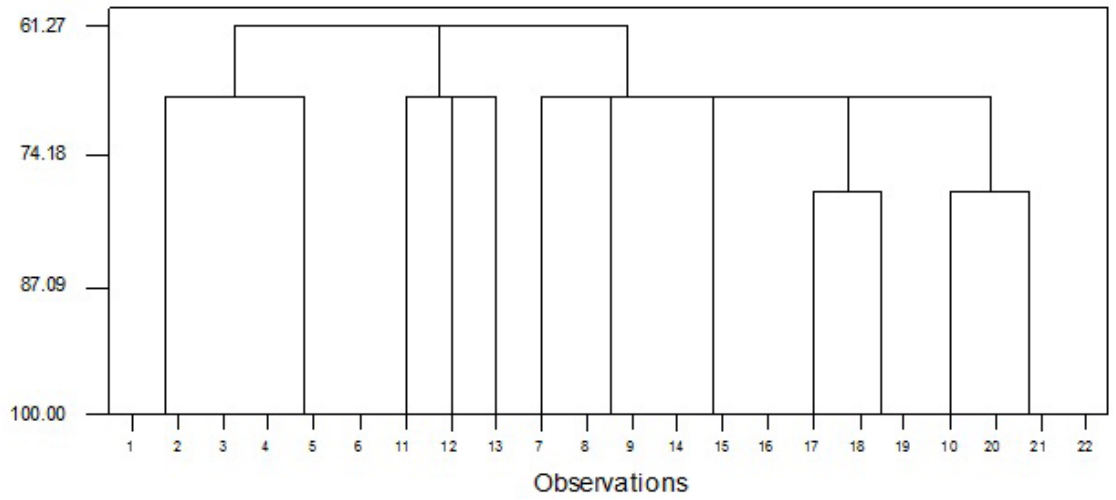

Figure 3. Dendogram of 22 Higher Education Institutions.

There are 3 clusters formed with 6 HEIs belonging to Cluster 1, 13 to Cluster 2, and 3 to Cluster 3. The HEIs in Cluster 1 are Xavier University, Liceo de Cagayan University, Capitol University, Cagayan de Oro College, Lourdes 
College, and Pilgrim Christian College. These are all private schools with accredited higher degree programs. The HEIs in Cluster 2 include AMA Computer College, Informatics, Opol Community College, Tagoloan Community College, Initao Community College, Christ the King College, Gingoog City Junior College, Gingoog Christian College, Southern Philippines College, Colegio de Santo Nino Jasaan, St. Peter's College, and St. Rita’s College. In Cluster 3 are Mindanao University and Science and Technology, Misamis Oriental Science College of Agriculture Technology, and Mindanao State University-Naawan.

Table 2. Clustering of HEIs based on the Cluster Algorithm

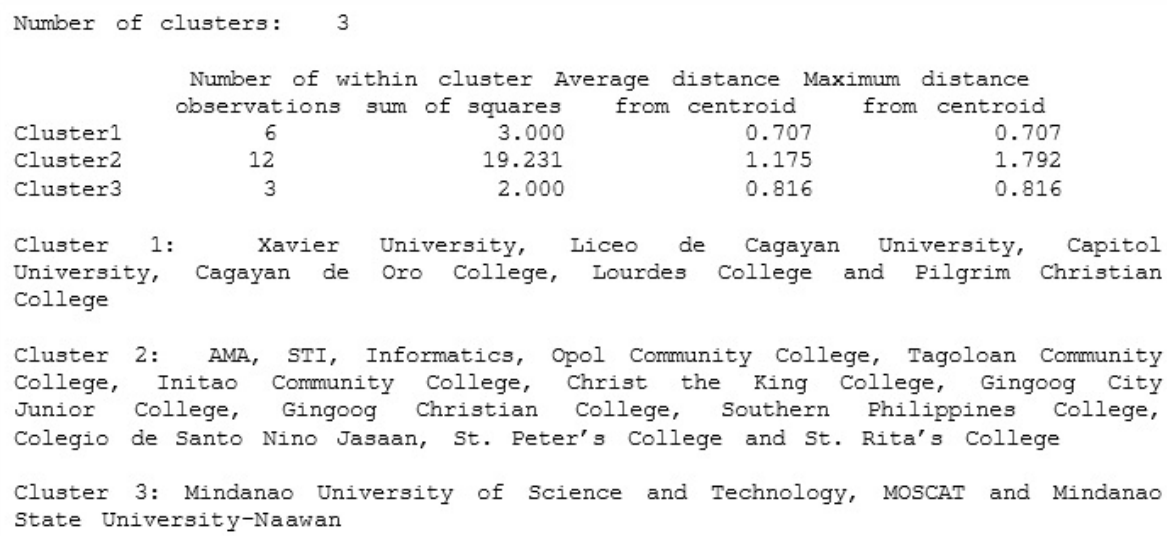

\section{Policy Variables}

\section{Context}

Cluster Centroids

$\begin{array}{lrrrc}\text { Variable } & \text { Cluster1 } & \text { Cluster2 } & \text { Cluster3 } & \text { Grand centrd } \\ \text { classifi } & 2.0000 & 1.7692 & 1.0000 & 1.7273 \\ \text { accredit } & 1.0000 & 2.0000 & 1.0000 & 1.5909\end{array}$


Clusters 1 and 2 are above the grand centroid, indicating that the HEIs are private schools with the exception of three community colleges in Opol, Tagoloan, and Initao that are in Cluster 2. Cluster 3 is below the grand centroid 1.7273, which means the HEIs are classified as public schools (chartered state institutions).

As to the quality of instruction, Clusters 1 and 3 are both below the grand centroid. Since the coding is such that $1=$ accredited and $2=$ not accredited, the values suggest that the HEIs in Clusters 1 and 3 have accredited higher degree programs, while those in Cluster 2 do not have accredited programs.

\section{Inputs}

\begin{tabular}{|c|c|c|c|c|}
\hline \multicolumn{5}{|c|}{ Cluster Centroids } \\
\hline Variable & & & & \multirow{2}{*}{$\begin{array}{c}\text { Grand centrd } \\
3.6364\end{array}$} \\
\hline faculty & \multirow{2}{*}{$\begin{array}{l}4.5000 \\
4.5000\end{array}$} & \multirow{2}{*}{$\begin{array}{r}3.0769 \\
2.9231\end{array}$} & \multirow{2}{*}{4.3333} & \\
\hline faciliti & & & & 3.4545 \\
\hline
\end{tabular}

Clusters 1 and 3 are both above the grand centroid. Cluster 1 has excellent faculty development program $($ mean $=4.5)$ and school facilities $($ mean=4.5). Cluster 3 has very good faculty development program and very sufficient school facilities. Cluster 2 has a value below the grand centroid, indicating that the HEIs' faculty development program (mean=3.0769) and school facilities $($ mean $=2.9231)$ are not that extensive and functional.

\section{Processes}

$$
\text { cluster Centroids }
$$

$\begin{array}{lrrrr}\text { Variable } & \text { Cluster1 } & \text { Cluster2 } & \text { Cluster3 } & \text { Grand centrd } \\ \text { scheme } & 3.0000 & 2.0000 & 4.0000 & 2.5455\end{array}$

Concerning the HEIs' preferred mainstreaming scheme, Cluster 1 preferred the offering of technopreneurship as a cognate course and as a topic in economics and business subjects. Cluster 2 preferred the offering of technopreneurship as a topic in economics or business subject, while Cluster 3 preferred scheme D 
$($ mean $=4.000)$ that covers all mainstreaming schemes.

\section{Output}

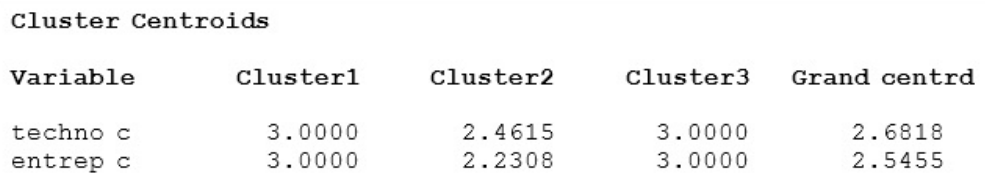

In terms of technical and entrepreneurial competencies, students of HEIs in Clusters 1 and 3 posted the high level of competencies $(x=3.000)$, which could be attributed to the HEIs' competent faculty and excellent facilities being accredited public and private HEIs. Cluster 2, on the other hand, has values below the grand centroid, indicating a lack of both technical and entrepreneurial competencies among the students.

\section{Outcome}

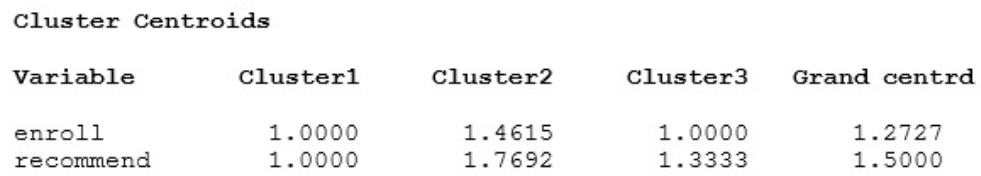

There is a high demand for technopreneurship in Clusters 1 (mean=1.000) and 3 (mean $=1.000)$, revealing that a large percentage of the students will enroll in and recommend the course or subject. The grand centroid of 1.500 denotes that the higher the centroid, the less likely the students will enroll in the course. Students in Cluster 2, however, will only enroll in the course (mean=1.4615) but will not recommend (mean=1.7692) it to other students.

\section{Theory Formulation and Validation}

Observations made on the Context Variables in the cluster analysis lead to the conclusion that public chartered institutions (SUCs) and private universities generally have programs that are accredited, whereas most of the smaller private 
colleges and non-chartered state schools do not have accredited programs. Such finding can be explained by the fact that accreditation is a requirement for university status and a budget requirement for state colleges. It may also be of interest to look into the quality of instruction when the HEIs are grouped according to their accreditation status. Since teacher education is a common program in all schools, the board exam average passing rate in this program is taken as a surrogate measure of the quality of instruction. Table 1 shows the results of the comparison.

Table 3. T-Test for Comparing Quality of Instruction (Based on Teacher Ed Board)

\begin{tabular}{|c|c|c|c|c|}
\hline Accreditation & Mean & $\begin{array}{c}\text { Mean } \\
\text { Difference }\end{array}$ & T-Value & Interpretation \\
\hline Accredited & 40.6 & \multirow{2}{*}{24.1} & 2.29 & SIGNIFICANT \\
\cline { 1 - 2 } $\begin{array}{c}\text { Non- } \\
\text { accredited }\end{array}$ & $\mathbf{1 6 . 5}$ & 24 & \\
\hline
\end{tabular}

The table shows a mean difference of 24.1 with a t-value of 2.29 , which exceeded the required value for significance of .05 . That is, a significant difference in the means existed. Hence, the HEIs' quality of instruction (as measured by the board passing rates) is significantly influenced by their accreditation status. In fact, accredited institutions tended to have higher board exam passing rates than the non-accredited ones.

\section{Theory \#1. Quality of instruction between accredited and non-accredited institutions significantly differs.}

Accreditation is a process by which an institution volunteers to be evaluated by a specific, non-governmental accrediting body (Aquino, 2008). The conferral of this accreditation indicates the institution has met pre-set standards of the accrediting body. It does not mean that all institutions with similar accreditation are the same; however, there is an implied assurance that a minimal level of quality is provided by an accredited institution.

For students, accreditation provides an assurance that an institution or program meets standards of quality, thereby affording students eligibility in 
gaining acceptance and transferring credits to similarly accredited institutions and eligibility for participation in certain programs of governmental aid or programs of scholarship grants sponsored by private foundations.

Observations made on the Input Variable from cluster analysis appear to support the following theory:

Theory \# 2: Good faculty development programs coupled with excellent facilities further enhance the technical and entrepreneurial aptitude of students.

Regression Analysis was performed to test this theory as shown below.

Table 4. Regression Analysis: Technical Aptitude versus Faculty, Facilities

\begin{tabular}{|c|c|c|c|c|c|}
\hline Variable & Coef & SE Coef & T & P & Interpretation \\
\hline Constant & 0.7474 & 0.3069 & 2.44 & 0.025 & \\
\hline Faculty & 0.4924 & 0.1528 & 3.22 & 0.004 & SIGINIFICANT \\
\hline Facilities & -0.0106 & 0.1353 & -0.08 & 0.939 & $\begin{array}{c}\text { NOT } \\
\text { SIGNIFICANT }\end{array}$ \\
\hline \multicolumn{7}{|l}{$\mathbf{S}=\mathbf{0 . 3 0 5 0} \quad$ R-Sq $=\mathbf{6 6 . 3} \% \quad$ R-Sq(adj) $=\mathbf{6 3 . 3} \%$} \\
\hline
\end{tabular}

The tabular data above show a significant relationship between Technical Aptitude and Faculty Development $(\mathrm{T}=3.22)$. The $66.8 \%$ of technical aptitude can be explained by the HEIs' quality of faculty development program and facilities.

The teachers are the first-line service providers, and their work performance is crucial to the operation of the school (Aquino, 2008). An important principle a teacher must keep in mind is making the learning environment as "stimulating" as possible, seeing to it that every stimulus in the classroom contributes to learning (Palma, 2007).

Quality education cannot rise above the quality of teachers, and the quality of teachers is dependent on the quality of schools that train them (Cortes, 1991). Thus, as teachers learn about the potential of technology, they restructure their physical classroom environments to allow presentation space, group work space, and flexible space for multiple activities (Bitter \& Legacy, 2008). When students have individual access to computers, teachers can individualize learning 
opportunities and allow students to work at their own pace; students seem to focus on their work longer (Tiene \& Luft, 2001) and in the process of doing, improve their technical competencies.

Results of this study lend support to the theory with respect to technical competencies.

Another regression analysis was made to measure further the validity of the theory.

Table 5. Regression Analysis: Entrep Aptitude versus Faculty, Facilities

\begin{tabular}{|c|c|c|c|c|c|}
\hline Variable & Coef & SE Coef & T & P & Interpretation \\
\hline Constant & 1.1225 & 0.4945 & 2.27 & 0.035 & \\
\hline Faculty & -0.2016 & 0.2462 & -0.82 & 0.423 & $\begin{array}{c}\text { NOT } \\
\text { SIGNIFICANT }\end{array}$ \\
\hline Facilities & 0.4900 & 0.2181 & 2.25 & 0.037 & SIGNIFICANT \\
\hline \multicolumn{7}{|r}{$\mathbf{S}=\mathbf{0 . 4 9 1 5} \quad$ R-Sq $=\mathbf{3 4 . 0} \% \quad$ R-Sq(adj) $=\mathbf{2 7 . 0} \%$} \\
\hline
\end{tabular}

The above tabular values show a significant relationship between facilities ( $T=$ 2.25) and entrepreneurial aptitude. Hence, availability of school facilities can enhance students' entrepreneurial aptitude.

School facilities or physical plant consists of the grounds, buildings, and the various equipment and furniture within the school grounds and inside the school buildings. The primary function of the physical plant is to provide an environment conducive to learning (Franco, 2006).

Moreover, the statistical result shows no significant relationship between students' entrepreneurial aptitude and HEI's faculty development program. This finding can be explained by the difference in the teaching methods used for technopreneurship education. Thus, available evidence lends partial support to the theory with respect to entrepreneurial competencies.

The use of experience-based teaching methods is crucial to the development of students' entrepreneurial aptitude. Therefore, in order to mainstream technopreneurship across curricula, the use of action-oriented pedagogies should be prominent in all disciplines. This kind of methodology, however, is labor intensive and costly and requires specific training. So, more educators need to be trained in this field (European Commission, 2008).

Two unusual observations were noted and carefully examined in the next discussion. 
In summary, technical aptitude was influenced by faculty development program and not by facilities. However, entrepreneurial aptitude was influenced by the facilities, not by the faculty.

Regression Analysis was performed to test this theory as shown below.

Table 6. Regression Analysis: Scheme versus Classification, Accreditation

\begin{tabular}{|c|c|c|c|c|c|}
\hline Variable & Coef & SE Coef & T & P & Interpretation \\
\hline Constant & 4.8690 & 0.8782 & 5.54 & 0.000 & \\
\hline Classification & -0.5119 & 0.4054 & -1.26 & 0.222 & NOT SIGNIFICANT \\
\hline Acrreditation & 0.9048 & 0.3672 & -2.46 & 0.023 & SIGNIFICANT \\
\hline \multicolumn{6}{|c}{$\mathbf{S}=\mathbf{0 . 8 4 1 4} \quad \mathbf{R}-\mathbf{S q}=\mathbf{3 0 . 9} \% \quad \mathbf{R}-\mathbf{S q}(\mathbf{a d j})=\mathbf{2 3 . 6 \%}$} \\
\hline
\end{tabular}

Regression Analysis reveals a significant t-value of -1.87 in favor of the public chartered HEIs, i.e. the public chartered HEIs appear to embrace all the mainstreaming options more than the private schools. Thus, if mainstreaming were to be experimented, the SUC's would be the best place to start with it.

According to the study of Charisse Gulosimo, the teachers in the public HEIs were more likely to be promoted to the professor than those in private HEI, thus encouraging teachers to deliver quality education to their students. Thus, students in public HEIs are much more likely to pass the licensing exams than students in private HEIs.

Results of this study provide evidence of a correlation between mainstreaming scheme and accreditation. This relationship indicates the feasibility of adoption of all schemes in accredited HEIs.

Cluster analysis on the output variables suggests the following theory:

Theory \#3. There is a direct relationship between accreditation programs and technical and entrepreneurial aptitude of students in HEIs.

To test this theory, Regression Analysis was performed. 
Table 7. Regression Analysis: Techno Aptitude versus Classification, Accreditation

\begin{tabular}{|c|c|c|c|c|c|}
\hline Variable & Coef & SE Coef & T & P & Interpretation \\
\hline Constant & 3.3571 & 0.3840 & 8.74 & 0.000 & \\
\hline Classification & 0.2143 & 0.1773 & 1.21 & 0.242 & NOT SIGNIFICANT \\
\hline Acrreditation & -0.7143 & 0.1606 & -4.45 & 0.000 & SIGNIFICANT \\
\hline \multicolumn{7}{|c|}{$\mathbf{S}=\mathbf{0 . 3 6 7 9}$ R-Sq = 51.6\% R-Sq(adj) $=\mathbf{4 6 . 6 \%}$} \\
\hline
\end{tabular}

Table 8. Regression Analysis: Entrep Aptitude versus Classification, Accreditation

\begin{tabular}{|c|c|c|c|c|c|}
\hline Variable & Coef & SE Coef & $\mathbf{T}$ & $\mathbf{P}$ & Interpretation \\
\hline Constant & 2.8869 & 0.5042 & 5.73 & 0.000 & \\
\hline Classification & 0.1488 & 0.2328 & 0.64 & 0.530 & NOT SIGNIFICANT \\
\hline Acrreditation & 0.6905 & 0.2108 & -3.27 & 0.004 & SIGNIFICANT \\
\hline
\end{tabular}

The above tables show a significant correlation between accreditation and technical and entrepreneurial aptitude of HEI students. Results indicate the viability of mainstreaming technopreneurship education in accredited HEIs since their students are more dynamic than those in non-accredited HEIs. The fact that there is no direct association between classification and technical $(T=1.21)$ and entrepreneurial $(\mathrm{T}=0.64)$ aptitude, classification of HEIs is not that insignificant.

The theory suggests that students in accredited HEIs have higher technical and entrepreneurial aptitude than those in non-accredited HEIs. Hence, it is more effective to mainstream technopreneurship in accredited HEIs because of their students' readiness for the program. According to Thorndike's law of readiness, learners learn best when they are physically, mentally, and emotionally ready for training. Readiness involves the ability to participate effectively in the desired learning activity. Readiness depends on the learner's maturity, which is a product of inheritance and experience (Andres $\&$ Francisco, 2007). Results lend support to the theory on accreditation.

Finally, when the Outcome Variables were measured, cluster analysis generated the following theory: 
Theory\#4. The level of demand for the technopreneurship is greatly influenced by accreditation.

Regression analysis was used to test the theory.

Table 9. Regression Analysis: Enroll versus

Classification, Accreditation

\begin{tabular}{|c|c|c|c|c|c|}
\hline Predictor & Coef & SE Coef & T & P & Interpretation \\
\hline Constant & 0.6429 & 0.3840 & 1.67 & 0.110 & NOT SIGNIFICANT \\
\hline Classification & -0.2143 & 0.1773 & -1.21 & 0.242 & SIGNIFICANT \\
\hline Accreditation & 0.7143 & 0.1606 & 4.45 & 0.000 & R-Sq(adj) $=\mathbf{4 6 . 6 \%}$ \\
\hline \multicolumn{7}{|c}{$\mathbf{S}=\mathbf{0 . 3 6 7 9}$} & R-Sq $=\mathbf{5 1 . 6 \%} \quad$ R-S \\
\hline
\end{tabular}

Accreditation has always been cited as an innovative means of enhancing quality (Arcelo, 2003). Statistical results reveal that the $51.6 \%$ of students to enroll in the course can be explained by the HEIs' accreditation. Data show a significant relationship between enrollment and accreditation. Meanwhile, there was no link between enrollment and classification. It can then be deduced that the mainstreaming of technopreneurship education will be most feasible in both public and private HEIs with accredited higher education degree programs.

\section{Theories from Unusual Observations: Anomaly Detection}

In the preceding results and discussion, statistical analyses revealed a direct correlation between HEIs' quality of instruction and their students' technical and entrepreneurial aptitude; hence, HEIs with accredited higher degree programs tend to have students with high technical and entrepreneurial aptitude. Some observations, however, did not follow such pattern. One HEI has good faculty development program and facilities yet have students with low technical and entrepreneurial aptitude.

Another set of findings reveal a significant correlation between mainstreaming schemes and classification of HEIs; hence, private HEIs find mainstreaming technopreneurship as a topic to be feasible. However, one observation did not go along this pattern. One private HEI considered another mainstreaming scheme to be most feasible. 
Such observations mask the true strength of the relationship between educational systems and mainstreaming schemes. Hence, such relationship should be carefully analyzed because its existence, if persistently observed, could lead to alternative theories about the relationship between educational system attributes and mainstreaming schemes.

\section{Description of Unusual Observation}

Observation \#10 registered moderate faculty development (3.0) yet with very high technical aptitude among students (3). It is also an unusual observation because an HEI with moderate faculty development program is expected to have students with moderate entrepreneurial aptitude, but in this case, the HEI had students with very low entrepreneurial aptitude (1) index.

Observation \#8 is a private institution (2.0) expected to choose "introduction as a topic" as a mainstreaming scheme, but it chose to introduce technopreneurship as a technical-vocational course (5.0).

Such unusual observations are indicative of possible alternative theories that would explain why they behaved as such. One possible explanation is the accreditation of HEIs. The variations could be attributed to the difference in the availability of educational resources. This theory will be validated in the next section.

\section{Difference in Students' Technical Aptitude between Accredited and Non- accredited HEIs}

One way to validate the theory is to test whether the observed significant difference will continue to hold when students' technical competencies are measured against the accreditation of HEIs. Table 9 shows the T-test results.

Table 10. Two-Sample T-Test and CI: techni-acre, tecni-non acre

\begin{tabular}{|l|l|l|l|l|l|}
\hline Competencies & Accredited & $\begin{array}{l}\text { Non- } \\
\text { Accredited }\end{array}$ & $\begin{array}{l}\text { Mean } \\
\text { Difference }\end{array}$ & T-Value & Interpretation \\
\hline Technical & 2.778 & 2.308 & 0.470 & 2.37 & SIGNIFICANT \\
\hline
\end{tabular}

As shown, the accredited HEIs had higher students' technical aptitude mean (2.778) than the non-accredited HEIs (2.308). The mean difference of 
0.470 with a $T$ value of 2.37 , which exceeded the critical value, was found to be significant. It can then be deduced that accreditation is a significant variable in the determination of students' level of technical aptitude.

\section{Difference in Students' Entrepreneurial Aptitude between Accredited and Non-accredited HEIs}

Table 10 shows the T-test results when students' entrepreneurial aptitude of both accredited and non-accredited HEIs were considered.

Table 11. Two-Sample T-Test and CI: entrep-acre, entrep-non acre

\begin{tabular}{|l|l|l|l|l|l|}
\hline Competencies & Accredited & $\begin{array}{l}\text { Non- } \\
\text { Accredited }\end{array}$ & $\begin{array}{l}\text { Mean } \\
\text { Difference }\end{array}$ & T-Value & Interpretation \\
\hline Entrepreneurial & $\mathbf{2 . 4 4 4}$ & 1.769 & 0.675 & 3.16 & SIGNIFICANT \\
\hline
\end{tabular}

Tabular values reveal that the entrepreneurial aptitude means of students in accredited and non-accredited HEIs differed significantly. The mean difference of 0.675 posted a T-value of 3.16, which exceeded the required value for significance at .05 probability level. Hence, students' entrepreneurial aptitude is significantly associated with HEIs' accreditation status. In fact, accredited institution, as compared to non-accredited ones, tend to have students with higher entrepreneurial aptitude.

Modified Theory: Students' technical and entrepreneurial aptitudes are significantly related to the quality of faculty development but only when the institution is accredited.

\section{Difference in Faculty Development between Accredited and Non-accredited HEIs}

Because of the new finding, a re-analysis on the quality of faculty development between non-accredited and accredited HEIs was done. 
Table 12. Two-Sample T-Test and CI: faculty-acre, faculty-non

\begin{tabular}{|l|l|l|l|l|l|}
\hline Variable & Accredited & $\begin{array}{l}\text { Non- } \\
\text { Accredited }\end{array}$ & $\begin{array}{l}\text { Mean } \\
\text { Difference }\end{array}$ & T-Value & Interpretation \\
\hline Faculty Devt & 4.667 & 3.308 & 1.359 & 6.37 & SIGNIFICANT \\
\hline
\end{tabular}

Tabular values reveal a significant difference in the faculty development means of institutions with accredited and non-accredited status. The mean difference of 1.359 posted a T-value of 6.37 , which exceeded the required value for significance at .05 probability level. Hence, faculty development is significantly associated with the accreditation status of the institution. In fact, accredited institutions tend to have higher faculty development index than the non-accredited institutions.

\section{Difference in mainstreaming scheme between accredited and non-accredited HEIs}

Table 13. Two-Sample T-Test and CI: scheme-acre, scheme-non acre

\begin{tabular}{|l|l|l|l|l|l|}
\hline Variable & Accredited & $\begin{array}{l}\text { Non- } \\
\text { Accredited }\end{array}$ & $\begin{array}{l}\text { Mean } \\
\text { Difference }\end{array}$ & T-Value & Interpretation \\
\hline Scheme & 3.111 & 2.154 & 0.957 & 2.65 & SIGNIFICANT \\
\hline
\end{tabular}

Tabular values reveal a significant difference in the mainstreaming scheme means of accredited and non-accredited HEIs. The mean difference of .957 posted a T-value of 2.69, which exceeded the required value for significance at .05 probability level. Hence, the HEIs' choice of mainstreaming scheme is significantly associated with the HEIs' accreditation status. In fact, accredited institutions tend to choose scheme 3 , which introduces technopreneurship as a 3-unit cognate and a topic in economics and entrepreneurship subject.

The following theory is generated:

Modified Theory: Accreditation significantly influences the HEIs' choice of mainstreaming scheme.

Accreditation, put simply, is a procedure by which an authoritative body formally recognizes that a school is competent to carry out specific tasks, 
including the issuances of college degrees.

Degrees earned from schools accredited by the regional associations are ensured to be considered valid by employers and other educational institutions. Schools become accredited when they have been formally evaluated according to standards issued by the Commission on Higher Education. The criteria used by these accreditation commissions generally require that students spend significant quantities of time or money on their education as well as meet a certain set of core competencies.

Participation in the accreditation process is voluntary; no school is required to become accredited. However, a lack of accreditation could mean a lack of government funding and financial aid opportunities. Accreditation also brings a sense of legitimacy to an institution; those who are accredited are held in higher esteem than those who are not. Therefore, for the mainstreaming scheme to be feasible, it is highly desirable for HEI to obtain accreditation from one of the accrediting bodies in the country.

As earlier discussed, there were unusual observations that set a different pattern of situations, thereby generating modified theories. The modified theories are as follows: (1) Students' level of technical and entrepreneurial competencies is significantly associated with the quality of faculty development but only when the institution is accredited and (2) Accreditation significantly influences the HEIs' choice of mainstreaming scheme.

\section{CONCLUSIONS}

Based on the findings of the study, the following conclusions are drawn: Accreditation determines the feasibility of the adoption of all mainstreaming schemes. Such that it affects the level of demand for technopreneurship education. Students with high technical and entrepreneurial aptitudes will most likely enroll in technopreneurship course. The HEI's quality of faculty development program and facilities greatly influence the effectiveness and efficiency of the delivery of technopreneurship education.

\section{RECOMMENDATIONS}

In relation to the findings of this study, the following recommendations are advanced for the Commission on Higher Education to consider: 
1. With demand for technopreneurship education, the Commission may establish a steering committee to evaluate the technopreneurship mainstreaming schemes in Higher Education Institutions. The Commission may then create Regional Centers responsible for organizing and coordinating initiatives that promote technopreneurship education. These centers can build up a critical mass of activities at a local level, encourage the sharing of best practices and tools, and provide support for networking among educators, entrepreneurs, and students. Initiatives will include training teachers and mobilizing technopreneurs to operate in the classroom.

2. Since accreditation significantly influences the HEIs' choice of the mainstreaming scheme, the Commission may create a broad framework for accreditation system to validate formal learning and practical activities that favor technopreneurship development.

The following recommendations are advanced for the Higher Education Institutions to consider:

1. Since technopreneurship is not yet integrated into the tertiary curricula, HEIs may embed technopreneurship in all disciplines. One effective way of doing so is to establish a department responsible for implementing and monitoring the technopreneurship program. Such department can be placed under the College of Commerce or Business School or Information Technology.

2. Since there is high demand for technopreneurship education among students, technopreneurship may be made as one of the topics in business and computer subjects. In addition, HEIs may give students the opportunity to attend seminars and lectures on technopreneurship. HEIs may also integrate technopreneurship as a required course into the general curriculum.

3. Since faculty development greatly influences the technical and entrepreneurial competencies of students, HEIs may put in place an incentive system for faculty and staff that they may motivated to engage themselves and students in technopreneurship and its related activities. 


\section{LITERATURE CITED}

Arcelo, A.A. (2003). In pursuit of continuing quality in higher education through accreditation: The Philippine experience: International Institute for Educational Planning, UNESCO.

Aquino, G. (2008). Curriculum Innovation. National Bookstore.

Bagozzi, R.P. (1998). Marketing Management.

Bitter, G.L. (2008). Using Technology in the Classroom. Library of Congress.

Cortes, J.R. (1991). Quezon City: University of the Philippines College of Education.

European Commsission (2008). Best procedure project: "Entrepreneurship in higher education, especially in Non-Business Studies": Final report of the expert group.

Franco, E. (2006). Educational planning. Center for development management and productivity.

Gibb, A.A. (2005). "The future of Entrepreneurship Education, determining the basis for coherent policy and practice" Chapter 2 in Kyro, $\mathrm{P}$ and Carrier, C. The Dynamics of Learning Entrepreneurship in a Cross Cultural University Context' University of Tampere Research Center for Vocational and Professional Education. Pp. 44-68.

Gisrich, Punj, David W. Stewart. (1983). Journal of marketing, pages 134-148.

Palma, J.C. (2007). Curriculum development system: A handbook for school practitioners in basic education. 